\title{
Contribution of Organizational Commitment, Lesson Study, and Teacher Professionalism to Learning Quality
}

\author{
Amrina Rosyada *, Aslamiah, M. Saleh \\ Master Program of Education Management, Universitas Lambung Mangkurat, Banjarmasin 70123, Indonesia
}

Article history:

Submission August 2020

Revised September 2020

Accepted September 2020

*Corresponding author:

E-mail:

amrinarosyada123@gmail.com

\begin{abstract}
The aims of this study describes and analyzes the contributions: organizational commitment to the quality of learning; school-based lesson study (SBLS) on the quality of learning; an organizational commitment to professionalism; SBLS towards professionalism; professionalism towards the quality of learning; an organizational commitment to the quality of learning through professionalism; and SBLS on the quality of learning through professionalism. This research used a quantitative method by distributing questionnaires with a Likert scale. The study population was 128 teachers with a sample of 97 teachers who were selected by proportional random sampling at State Middle Schools in Banjarbaru City-collecting data using instruments that have been valid and reliable. Data were analyzed descriptively and path analysis. The research results show: (1) organizational commitment has a contribution to the quality of learning, (2) SBLS has a contribution to the quality of learning, (3) organizational commitment has a contribution to professionalism, (4) SBLS has a contribution to professionalism, (5) ) professionalism has a contribution to the quality of learning, (6) organizational commitment has a significant indirect contribution to the quality of learning through professionalism, and (7) SBLS does not have an indirect contribution to the quality of learning through professionalism.
\end{abstract}

Keywords: Organizational commitment, school-Based Lesson Study (SBLS), teacher professionalism, quality of learning

\section{Introduction}

The times, science, and technology encourage society's increasing demands for qualified education in Indonesia (Dewi \& Primayana, 2019). Qualified education can produce quality human resources (Tayibnapis, Wuryaningsih, \& Gora, 2018). In the end, this will make a country more advanced and develop rapidly in science and technology is most needed in responding to the challenges of the times in the future (Sonhadji, 2004).

As formal educational institutions, schools are a place to produce quality human resources through a good quality education process (Ashadi, 2017). In other words, education is the center of the process of developing society
(Pedersen, Nørgaard, \& Köppe, 2018). Education is a social right and an individual bond concerning the state (Marshall, 1950). So, indeed, improving the quality of education is a development target in the national education field and is an integral part of efforts to improve human quality (Shelvia, Ahmad, \& Mahrita, 2020). Therefore, to create quality human resources, in this case, competent graduates and per society's demands, the school must carry out a quality learning process, both national and international quality standards (Sudarsana, 2018).

The average value of the National Examination (UN) at the SMP / MTs level nationally and the level of South Kalimantan Province in 2018 decreased from 2017. Besides, based on the UN

How to cite:

Rosyada, A. (2020). Contribution of organizational commitment, lesson study, and teacher professionalism to learning quality. Journal of K6, Education, and Management, 3 (2), 118 - 127. doi: 10.11594/jk6em.03.02.03 
results statistics published by the Ministry of Education and Culture, of the 14 State Junior High Schools that held the UN, almost all (11 schools) were State Middle Schools in Banjarbaru City, the average UN score decreased from 2015 to 2017 (Huda, 2018). One of the problems that cause a decline in the quality of graduates is the quality of learning, which is still not optimal (Rahman, 2018). It could also be because the way students receive and understand lessons is also a part of learning that is often overlooked (Frick, Chadha, Watson, Wang, \& Green, 2009).

To maximize the results of education in society and achieve success and sustain it, an open education for all learners is the primary key (Ossiannilsson, Altinay, \& Altinay, 2016). It is essential not only to assess learning questions academically but also to advocate for the learning students need for use in society (Saliyeva \& Levesley, 2018). It is suspected that teachers who are professional and have ethical organizational commitment can improve the quality of learning in schools, especially the quality of the learning process (Sastrawan, 2016). Professionalism is from knowledge and experience, so the more knowledge and experience a teacher has, the more professional his field will be (Sulaiman, Damai, \& Effendi, 2019). Teachers need to develop themselves to gain experience with various relevant activities (Boekaerts, 1999). One of them, teachers who carry out Lesson Study activities, also contributes to improving the quality of learning.

Teachers contribute an essential role in improving the quality of education (Isniwati, Wahdini, \& Saleh, 2020; Poernamawijayai, Sulaiman, Suriansyah, \& Dalle, 2018). It is not surprising that teachers' actions, values, and priorities for learning are national topics in many countries (Rimm-Kaufman \& Sawyer, 2004). The learning process's quality and failure are highly dependent on the ability and behavior of teachers in managing learning (Mujiati, Suriansyah, \& Effendi, 2019). Concerning the requirements of teacher professionalism, according to Glickman, the work commitment of teachers in their work is considered necessary (Naro, 2017). Furthermore, according to Naro, commitment is the teacher's attachment to the school where he works, the school needs commitment from the teachers so that the school's resources can be adequately maintained (Tuğrul Mart, 2013). Teacher commitment is an attachment to a task that leads to responsibility and an innovative and responsive attitude to advances in science and technology (Harahap, Suriansyah, \& Suhaimi., 2020). According to Glickman (1981), the level of teacher commitment can be described in a continuum that moves from low-level commitment to high-level commitment. A high commitment is one of the main requirements to produce professional teachers (Glickman, 1981). So, without realizing it, commitment is how the teacher tries to build his identity as someone with the status of 'teacher.' (Cynthia \& Wagoner, 2015). As a saying of the Buddha quoted by (McCullagh, 2013), commitment can be seen as "who we are today comes from yesterday's thoughts, and our present thoughts will shape our lives tomorrow." So, it means that a good teacher is a professional with a high level of commitment. He has a great sense of responsibility in him to develop education and provide the best lessons for his students so that it can be useful later. In other words, a good teacher will help their students to improve their learning achievements (Dalle, Haderani, \& Ulfah, 2010).

Based on research results found by Winarsih and Mulyani (2012), lesson Study can improve teacher professionalism, improve student learning processes, and outcomes. Other than that, Elvinawati, Sumpono and Amir (2012) concluded that the Lesson Study in the School I Chemistry course can improve the quality of the learning process and help student character building. Likewise, in Mathematics, what teachers do to develop students' abilities in understanding Mathematics requires Lesson Study (RAND Mathematics Study Panel \& Ball, 2003).

It shows that several efforts can be made to improve the quality of learning in the classroom, including increasing teacher professionalism, increasing organizational commitment, and implementing School-Based Lesson Study (SBLS) (Irmayani, Wardiah, \& Kristiawan, 2018). These three aspects are expected to be a determining factor in improving the quality of learning.

The aims of this study to describe and analyze the contribution: commitment organization on the quality of learning; lesson study school- 
based(LSBS) on the quality of learning; organizational commitment to professionalism; LSBS towards professionalism; professionalism towards the quality of learning; organizational commitment to the quality of learning through professionalism; and LSBS on the quality of learning through professionalism.

\section{Organizational commitment}

Meyer \& Allen (1997) define commitment as a psychological condition that describes the relationship between employees and their organization. It has a role in the decision to continue or terminate membership in the organization. Organizational commitment is the loyalty of employees or subordinates in helping the organization achieve its goals without resigning for various reasons (Juaini, Aslamiah, \& Suhaimi., 2020). This form of commitment is characterized by identification with the organization's goals and values, the desire to strive and maintain membership in the organization (Leithwood, Menzies, \& Jantzi, 1994).

Meyer \& Allen (1997) divide commitment into three dimensions as follows: 1) Affective commitment, appears for someone's wish to be part of an organization because there is an emotional bond, 2) Continuance commitment occurs when someone stays in an organization because he needs a salary and other benefits, or because the person does not find another job, and 3) Normative commitment, arises from the values in a person because of the awareness that commitment to the organization is a necessity as a member of the organization.

\section{Lesson study}

Lesson Study is a model of teacher coaching from Japan. In Japanese, it is called Jugyokenkyu, which consists of 2 words, namely jugyo, which means learning and kenkyu, which means research/study (Lewis \& Takahashi, 2013). In other words, a lesson study can be interpreted as an assessment of learning. Lesson Study is a form of improving the quality of learning and developing the competence of educators selected by Japanese educators (Abizar, 2017). It is crucial nowadays for teachers to monitor each other's learning strategies (Ma, Xin, \& Du, 2018). So, Lesson Study is, of course, something necessary to improve the quality of learning in schools. Lesson Study contains activities in the form of a systematic process to test the effectiveness of teaching to improve learning outcomes. Its systematic process is a collaboration between teachers in learning communities at schools to develop plans and learning tools (Plan stage), make observations (Do stage), and reflection and revision of learning plans cyclically and continuously (See stage) (Cerbin \& Kopp, 2006). It must be done in support of the formation of a learning system, which will later be considered the most appropriate to be applied to achieve satisfactory results for students.

In implementing the Lesson Study, educators collaboratively study the curriculum, formulate learning objectives. The goals of developing student life skills, design learning to achieve these goals, carrying out and observing a research lesson (studied learning) reflect then to discuss the learning that is reviewed and refined, and plans for the next lesson (Susilo, 2013).

There are two implementation models of lesson study (Nursafitri, 2015): 1) School-based lesson studies, namely lesson studies conducted in schools by teachers of various fields of study and school principals. In its implementation, schools may involve outsiders as experts such as lecturers from higher education institutions, and 2) Lesson studies are based on teacher groups. These namely, lesson studies are usually coordinated by groups of teachers and fostered by related education offices in specific work areas such as KKG and MGMP.

\section{Teacher professionalism}

Professionalism comes from English, namely professionalism, which means professional nature. According to Glickman (1981), Professional teachers have a high level of commitment to their work and have a high level of abstract thinking skills in dealing with problems. Furthermore, Glickman divides the teacher type into four quadrants based on the level of commitment (Level of Commitment) and abstraction (Level of Abstraction).

According to Glickman (1981), the level of teacher commitment can be described on a continuum moving from low-level commitment to high-level commitment. Teachers who are highly committed can be seen from 1) High concern for 
student and other teachers, 2) Extra time energy expended (providing more time and energy), and 3) Primary concern with doing more for others (pay attention by doing more for others) (Tuğrul Mart, 2013b).

Glickman (1981) explained that the level of the ability to think abstractly is shown in the ability of the teacher to analyze the teaching and learning process, formulate alternative solutions to learning problems and choose the best alternative in solving learning problems independently. Besides, abstract thinking behavior also includes teachers' ability to innovate and be creative in carrying out their duties as teachers (Suriansyah \& Aslamiah, 2012).

Also, teachers' status is seen as part of those who have little importance or use (Toch, 2010), but teachers still teach professionally. It is because of the professional nature and coordination that can be formed between the teacher and the student and also the student's guardian (Kassini, 2008). In other words, the professionalism shown by the teacher who always teaches in front of the class, no matter what level of commitment, is a real form of the teacher trying to commit to his identity status as a teacher. Therefore, teachers' professional identity is always identified with a concept that brings hope for the future and provides real change (Lopes, 2019).

\section{Quality of learning}

Goetsch and Davis define quality as a dynamic condition associated with originates, services, people, processes, and the environment that meet or exceed expectations. Crosby defines quality as individual conformity to standards/requirements/demands (Engkoswara, 2010). The quality of learning is mostly about the quality of the process and the quality of learning outcomes (Taurina, 2015). The quality of the learning process defined as the quality of learning activities carried out by teachers and students in class and elsewhere. In contrast, the quality of learning outcomes is the quality of learning activities manifested in the form of real learning outcomes achieved by students in the form of values (Hadis \& Nurhayati., 2010).

In the context of learning, the notion of quality includes the input, process, and output of learning (Nursafitri, 2015). Quality learning boils down to the teacher's ability in the learning process (Surakhmad, 2006). It means that quality learning is active learning, which in essence concerns the teacher's ability in the learning process in the classroom (Simon, Erduran, \& Osborne, 2006). In simple terms, teachers' abilities must be possessed by teachers to plan to learn, carry out the learning process, and evaluate learning (Berliner, 2001). Besides, according to Hooks, teachers must also respect and care for their students to form conditions where learning can begin in the deepest and closest way (Gewirtz \& Cribb, 2020). It means there are many ways to get the best quality of learning, with the center being the teacher who is in full control.

\section{Material and Methods}

This research uses the method of a survey with a quantitative approach through path analysis. The sample is from a population that has been determined per the object of research. The research sample required is as many as 97 teachers in 4 schools selected by proportional random sampling from a population of 128 teachers at State Junior High Schools in Banjarbaru City who implement SBLS activities. The data was collected using instruments that had been tested for validity and reliability. There are four questionnaires with a Likert scale to measure the four variables studied. They are the quality of learning $(Y)$ as the dependent variable, organizational commitment (X1), and School-Based Lesson Study (SBLS) (X2) as independent variables, and teacher professionalism ( $\mathrm{Z}$ ) as an intervening variable with a conceptual model between variables as shown in Figure 1.

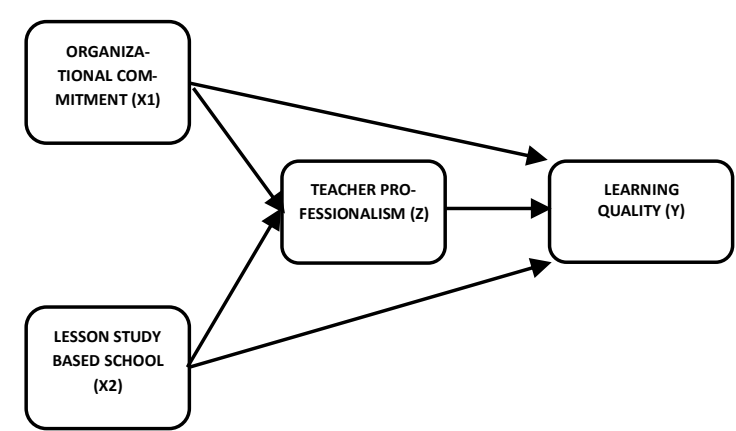

Figure 1. Model of the Conceptual Relationship between Variables and Bels

By the conceptual model above, path analysis is to answer the hypothesis (HO) in this study. 
Namely: $\mathrm{H}_{1}$ : there is no direct contribution of organizational commitment to teacher professionalism; $\mathrm{H}_{2}$ : there is no direct contribution of School-Based Lesson Study (SBLS) to teacher professionalism; $\mathrm{H}_{3}$ : there is no direct contribution of organizational commitment to the quality of learning; $\mathrm{H}_{4}$ : there is no direct contribution of School-Based Lesson Study (SBLS) to the quality of learning; $\mathrm{H}_{5}$ : there is no direct contribution of teacher professionalism to the quality of learning; $\mathrm{H}_{6}$ : there is no indirect contribution of commitment organization on the quality of learning through teacher professionalism, and $\mathrm{H}_{7}$ : there is no indirect contribution of School-Based Lesson Study (SBLS) to the quality of learning through teacher professionalism.

\section{Results and Discussion}

The descriptive analysis of the respondents' responses to the four research variables shown in Table 1 in the form of mean and classification based on calculations using the ideal mean (Mi) and ideal standard deviation (Sdi). The descriptive data in Table 1 means that the respondents gave the highest emphasis in filling out the research questionnaire on the organizational commitment variable and the lowest emphasis on the teacher professionalism variable.

The prerequisite analysis showed that the research data were normally distributed and linear. Besides, the data did not show multicollinearity symptoms, and there were no heteroscedasticity problems. All variables have met the requirements for further analysis, so that hypothesis testing followed by the path analysis with a summary of the results in Table 2.

The results of the path analysis, as shown in Table 2, are used to answer the seven research hypotheses formulated, the decisions in Tables 3 and 4. Table 3 summarizes the decisions $\mathrm{H}_{1}, \mathrm{H}_{2}$, $\mathrm{H}_{3}, \mathrm{H}_{4}$, and $\mathrm{H}_{5}$ with the criteria of less significance than $5 \%$, then the hypothesis $\left(H_{0}\right)$ is rejected. Based on the analysis in Tables 1, 2, 3, and 4, this study found a relationship between variables that explained.

Table 1. Mean and classification of research variables

\begin{tabular}{ccc}
\hline Variable & Mean & Classification \\
\hline Organizational Commitment & 3.34 & Medium \\
\hline SBLS & 3.09 & Medium \\
\hline Teacher Professionalism & 2.86 & Medium \\
\hline Quality of Learning & 3.02 & Medium \\
\hline
\end{tabular}

Table 2. Summary of path analysis results

\section{Substructural I}

Organizational Commitment, SBLS to Teacher Professionalism

\begin{tabular}{lllll}
\hline Variable & $\begin{array}{l}\text { Path } \\
\text { Coefficient }\end{array}$ & $\boldsymbol{T}$ & Sig. & $\boldsymbol{R}^{\mathbf{2}}$ \\
\hline $\begin{array}{l}\text { Organizational } \\
\text { Commitment }\end{array}$ & 0.125 & 1.646 & 0.013 & 0.976 \\
\hline SBLS & 0.865 & 11.390 & 0.000 & \\
\hline
\end{tabular}

\section{Substructural II}

Organizational Commitment, SBLS, Teacher Professionalism on Learning Quality

\begin{tabular}{lllll}
\hline Substructural II & $\begin{array}{l}\text { Path } \\
\text { Coefficient }\end{array}$ & $\boldsymbol{T}$ & Sig. & $\boldsymbol{R}^{\mathbf{2}}$ \\
\hline $\begin{array}{l}\text { Organizational } \\
\text { Commitment }\end{array}$ & -0.118 & -3.248 & 0.002 & 0.995 \\
\cline { 1 - 1 } & 0.326 & 5.887 & 0.000 & 0.000 \\
\hline $\begin{array}{l}\text { Teacher } \\
\text { Professionalism }\end{array}$ & 0.789 & 16.186 & \\
\hline
\end{tabular}


Table 3. Summary of hypothesis testing decisions $\mathrm{H}_{1}, \mathrm{H}_{2}, \mathrm{H}_{3}, \mathrm{H}_{4}$, and $\mathrm{H}_{5}$

\begin{tabular}{lll}
\hline Hypothesis $\left(\mathrm{H}_{0}\right)$ & Sig. & Decision \\
\hline $\begin{array}{l}\mathrm{H}_{1}: \text { there is no direct contribution of organizational commitment to teacher } \\
\text { professionalism }\end{array}$ & 0.000 & Rejected \\
\hline $\begin{array}{l}\mathrm{H}_{2}: \text { there is no direct contribution of School-Based Lesson Study (SBLS) to teacher } \\
\text { professionalism }\end{array}$ & 0.000 & Rejected \\
\hline $\begin{array}{l}\mathrm{H}_{3}: \text { there is no direct contribution of organizational commitment to the quality of } \\
\text { learning }\end{array}$ & 0.000 & Rejected \\
\hline $\begin{array}{l}\mathrm{H}_{4}: \text { there is no direct contribution of School-Based Lesson Study (SBLS) to the quality } \\
\text { of learning }\end{array}$ & 0.000 & Rejected \\
\hline $\mathrm{H}_{5}$ : there is no direct contribution of teacher professionalism to the quality of learning & 0.000 & Rejected \\
\hline
\end{tabular}

Table 4. Summary of hypothesis testing decisions $\mathrm{H}_{6}$ and $\mathrm{H}_{7}$

\begin{tabular}{|c|c|c|c|c|}
\hline \multirow[t]{2}{*}{ Hypothesis $\left(\mathrm{H}_{0}\right)$} & \multicolumn{2}{|c|}{$\begin{array}{l}\text { Relationship Coeffi- } \\
\text { cient }\end{array}$} & \multirow[t]{2}{*}{$z$} & \multirow[t]{2}{*}{ Decision } \\
\hline & Direct & Indirect & & \\
\hline $\begin{array}{l}\mathrm{H}_{6}: \text { there is no indirect contribution of organizational } \\
\text { commitment to the quality of learning through teacher } \\
\text { professionalism }\end{array}$ & -0.118 & 0.099 & 2.26 & Rejected \\
\hline $\begin{array}{l}\mathrm{H} \text { : there is no indirect contribution of School-Based Lesson } \\
\text { Study (SBLS) to the quality of learning through teacher } \\
\text { professionalism }\end{array}$ & 0.326 & 0.682 & 1.47 & Rejected \\
\hline
\end{tabular}

The relationship of organizational commitment, learning quality, and teacher professionalism

This study confirms that there is a significant and direct relationship between organizational commitment and learning quality. Besides, it also proves that the relationship between organizational commitment and learning quality through teacher professionalism does exist.

This finding is per the results of Mundiri's research (2015) concluded that organizational commitment could improve the quality of education. Besides, in general, the quality of teaching and learning for State Middle School teachers in the city of Banjarbaru is classified as medium. The average value on the sub-variable of teacher learning behavior shows a high value compared to other sub-variables. It shows that teacher behavior in the form of building positive attitudes of students towards learning, mastering scientific disciplines, understanding the uniqueness of students, mastering the management of educational learning, and developing personality and professionalism can be useful. Rosdiana's opinion (2016) that teachers committed to their work brings a positive impact by improving the learning quality in the classroom, as well as the results of their research, which concludes that teacher commitment affects learning outcomes and the effectiveness of the learning process of students.

The description above indicates that a teacher who has a strong commitment to his job will increase the quality of learning carried out by a teacher in the classroom (Day, 2002). A teacher's commitment to carrying out duties is indispensable in its function as an educator (Izzati, Suhariadi, \& Hadi, 2016). This study found that most of the teachers at State Junior High Schools in Banjarbaru City mastered scientific disciplines, understood the uniqueness of students and mastered the management of learning well. It has a positive impact on teaching and learning activities, which in turn makes a significant contribution to improving the quality of learning in class. It is in line with Solomon's opinion (2007) that teacher commitment can influence student achievement and an orderly climate conducive to learning.

Based on the descriptions above, a high organizational commitment teacher will always be dedicated to continuously evaluating and improving himself, especially in terms of mastery of knowledge (material), classroom management, and the effectiveness of the learning process, which will ultimately create learning quality. 
The relationship of School-Based Lesson Study (SBLB), the quality of learning, and teacher professionalism

This study identifies that there is a significant relationship between the implementation of school-based lesson study (SBLS) with the learning quality. There is also a direct relationship between the implementation of SBLS and the quality of learning. Besides, an indirect relationship was also identified between the implementation of SBLS and the quality of learning through teacher professionalism. This finding is similar to Sumani's research (2009), which concludes that lesson study has made a considerable contribution to improving the quality of learning.

In general, teacher activities in SBLS activities are in the medium category, and the learning quality of SMP Negeri teachers in Banjarbaru City is in the medium classification. It shows that the existence of SBLS activities that have been implemented can affect the improvement of the learning quality carried out by a teacher in the classroom. This study found that most of the teachers at State Junior High Schools in Banjarbaru City had mastered scientific disciplines, understood the uniqueness of students, and mastered the management of learning well. It has a positive impact on teaching and learning activities, which will make a significant contribution to improving the quality of learning in the classroom.

The description above indicates that the school-based lesson study (SBLS) activities conducted by teachers at the Banjarbaru City Junior High Schools have had a positive impact on improving the quality of learning. It is in line with Nursafitri's (2015) opinion that one of the efforts that can be implemented to improve the quality of learning is to carry out lesson studies. It concludes that lesson study can improve the quality of teachers/lecturers, and the quality of learning results in an increase in the quality of graduates in return. Besides, with SBLS activities, the teachers involved can be helped and trained in evaluating and correcting things that are lacking in the teaching and learning process. It is assisted by the observer who is in charge of recording and recording teacher learning activities so that the teacher concerned can improve the quality of teaching in the classroom. In other words, teachers can continue to make continuous improvements to achieve the desired learning goals (Edmonds, 2007). It is per Jusuf's research results (2018), who concluded that with the lesson study activities, educators/lecturers could improve their learning process with input from the observer team. The descriptions above said that the school-based lesson study (SBLS) activities carried out can have a significant influence and contribution to improving the quality of learning carried out by SMP Negeri teachers in Banjarbaru City who are involved in these activities.

\section{The relationship between teacher professional- ism and learning quality}

The findings above indicate that teachers' professional level at State Junior High Schools in Banjarbaru City affects the improvement of the quality of learning carried out by teachers in the classroom. High teacher professionalism will have a positive impact on improving education quality, especially the quality of learning about the quality or quality of education. It is in line with Rusman's opinion (2012), who explained that professional teachers are a determining factor for the quality education process and also the results of Sobri's research (2013) which states a possibility to improve the quality of learning, one of which is the professionalism of teachers.

This study found that most of the teachers at State Junior High Schools in Banjarbaru City had moderate and reasonable categories of professionalism. It sure has a positive impact on teaching and learning activities, which contributes to improving the quality of learning in class. This finding is in line with Sastrawan's research results (2016), which concluded that professional teachers would be able to improve the learning process, which will improve the quality of learning.

The description above is in line with Surakhmad's (2006) opinion, which states that quality learning boils down to the teacher's ability in the learning process. It means that quality learning is learning, which concerns the teacher's ability in the learning process in the classroom (Zakirova, 2016). In simple terms, the teacher's abilities that must be possessed by teachers are the ability to plan to learn, carry out the learning process, and 
evaluate learning, where these abilities are included in the professional competence of teachers.

The descriptions above concluded that a teacher must be able to plan, implement, and evaluate and improve the learning process that is carried out in the classroom. In other words, the teacher must have excellent professional competence. It is indispensable to achieve the desired learning objectives in order to realize quality learning.

\section{Conclusion and Recommendation}

The results show and conclude that: organizational commitment has a contribution to the quality of learning, SBLS has a contribution to the quality of learning, organizational commitment has a contribution to professionalism, SBLS has a contribution to professionalism, professionalism has a contribution to the quality of learning, organizational commitment has an indirect contribution to quality learning through professionalism and professionalism is an intermediary for the relationship between SBLS and the quality of learning, however, SBLS does not have a contribution to the quality of learning through professionalism.

This study recommended that stakeholders and education practitioners use this information as input in planning education quality improvement programs, the quality of learning in the classroom, and the quality of education in the school environment.

\section{Acknowledgment}

The author's gratitude goes to the supervisors and teaching lecturers of Master program of Education Management, Universitas Lambung Mangkurat, Banjamasin 70123, Indonesia. The latter has provided input to the author since the research's implementation until this article can be completed. May Allah SWT grants all those who have assisted the author until the publication of this article.

\section{References}

Abizar, H. (2017). Buku master lesson study: Panduan lengkap membentuk profesionalitas guru dalam kegiatan pembelajaran. . DIVA Press. .
Ashadi, F. (2017). Pengembangan sumber daya manusia dalam lembaga PAUD. Jurnal Pembelajaran Fisika, 5(4), 412-418.

Berliner, D. (2001). Learning about and learning from expert teachers. . International Journal of Educational Research, 35(5), 463-482.

Boekaerts, M. (1999). Self-regulated learning: Where we are today. International Journal of Educational Research, 31(6), 445457.

Cerbin, W., \& Kopp, B. (2006). Lesson Study as a Model for building Pedagogical Knowledge and Improving Teaching. International Journal of Teaching and Learning in Higher Education , 18(3), 250-257.

Cynthia, L., \& Wagoner. (2015). Measuring Music Teacher Identity: Self-Efficacy and Commitment Among Music Teachers. Bulletin of the Council for Research in Music Education, (205), 27-49.

Dalle, J., Haderani, \& Ulfah, R. (2010). The influence of interest, teachers, facilities and infrastructure, on the ability of students to calculate the volume and area of the geometry. Darul Ulum: Junal IImiah keagamaan, Pendidikan, dan Kemasyarakatan, 5(10), 3-24.

Day, C. (2002). School reform and transitions in teacher professionalism and identity. International Journal of Educational Research, 37(8), 677-692.

Dewi, P., \& Primayana, K. (2019). Effect of Learning Module with Setting Contextual Teaching and Learning to Increase the Understanding of Concepts . International Journal of Education and Learning, 1(1), 19-26.

Edmonds, C. (2007). Continuous quality improvement: Integrating best practice into teacher education. International Journal of Educational Management, 21(3), 232-237.

Elvinawati, Sumpono, \& Amir, H. (2012). Lesson study pada mata kuliah kimia sekolah I sebagai upaya peningkatan kualitas pembelajaran dan pembangunan karakter (character building). Jurnal Exacta, X(2), 1-10.

Engkoswara. (2010). Administrasi pendidikan. Alfabeta.

Frick, T., Chadha, R., Watson, C., Wang, Y., \& Green, P. (2009). College Student Perceptions of Teaching and Learning Quality. Educational Technology Research and Development, 57(5), 705-720.

Gewirtz, S., \& Cribb, A. (2020). Can Teachers Still Be Teachers?: The Near Impossibility of Humanity in the Transactional Workplace. In In Brown A. \& Wisby E. (Eds.), Knowledge, Policy and Practice in Education and the Struggle for Social Justice: Essays Inspired by the Work of Geoff Whitty (pp. 217232). London: UCL Press.

Glickman, C. (1981). Developmental supervision: alternative practices for helping teachers improve instruction. ASCD.

Hadis, A., \& Nurhayati. (2010). Manajemen mutu pendidikan. Alfabeta. 
Harahap, M., Suriansyah, A., \& Suhaimi. (2020). Relationship of Instructional Leadership, Organizational Climate and Teacher 's Commitment to Job Satisfaction. Journal of K6, Education and Management, 2(4), 260-270.

Huda, N. (2018, May). Mengejutkan! Nilai UN SMP Kalsel 2018 anjlok dibanding 2017, ternyata ini 3 faktor penyebabnya. Banjarmasin Post Online. Banjarmasin, South kalimantan.

Irmayani, H., Wardiah, D., \& Kristiawan, M. (2018). The strategy of SD Pusri in improving educational quality. International Journal of Scientific and Technology Research, 7(7), 113-121.

Isniwati, Wahdini, E., \& Saleh, M. (2020). Supervision and Participation in Teachers Working Group Toward the Teachers ' Professional Competence. Journal of K6, Education and Management, 2(4), 292-300.

Izzati, U., Suhariadi, F., \& Hadi, C. (2016). The Role of Self Competence on Affective Organizational Commitment of Vocational High School Temporary Teachers. The International Journal of Organizational Innovation, 8(4), 133139.

Juaini, Aslamiah, \& Suhaimi. (2020). The Influence of Principal 's Leadership Style, Teacher's Commitment and Work Spirit on Teacher' s Performance in Junior High School in Banjarbaru City. Journal of K6, Education and Management, 2, 211-217.

Jusuf, R. (2018). Peningkatan kualitas pembelajaran melalui lesson study. Primaria Educationem Journal, 1(1).

Kassini, I. (2008). Professionalism and Coordination: Allies or Enemies? American Annals of the Deaf, 153(3), 309-313.

Leithwood, K., Menzies, T., \& Jantzi, D. (1994). Earning Teachers' Commitment to Curriculum Reform. Peabody Journal of Education, 69(4), 38-61.

Lewis, C., \& Takahashi, A. (2013). Facilitating curriculum reforms through lesson study. International Journal for Lesson and Learning Studies. 2(3), 207-217.

Lopes, A. (2019). Still Building a Better World?: Research Reflections on Teacher Education and Identity. In In KowalczukWalêdziak M., Korzeniecka-Bondar A., Danilewicz W., \& Lauwers G. (Eds.), Rethinking Teacher Education for the 21st Century: Trends, Challenges and New Directions (pp. 27-42). Opladen; Berlin; Toronto: Verlag Barbara Budrich.

Ma, N., Xin, S., \& Du, J. (2018). A Peer Coaching-based Professional Development Approach to Improving the Learning Participation and Learning Design Skills of In-Service Teachers. Journal of Educational Technology \& Society, 21(2), 291-304.

Marshall, T. (1950). Citizenship and social class. UK: Cambridge University Press.

McCullagh, P. (2013). The origins of a commitment. In In Ted Freeman and the Battle for the Injured Brain: A case history of professional prejudice (pp. 13-32). Canberra: ANU Press.
Meyer, J., \& Allen, N. (1997). Preparing instruction objectives. Fearm Publishe, Inc.

Mujiati, M., Suriansyah, A., \& Effendi, R. (2019). Effect of Academic Supervision and School Culture on Teacher' $s$ Teaching Quality in Public Islamic Senior High School Banjarmasin. Journal of K6, Education and Management, 2(2), 126-132.

Mundiri, A. (2015). Komitmen organisasional sumber daya manusia dalam meningkatkan mutu pendidikan pesantren. . Jurnal Pendidikan Pedagogik, 3(1).

Naro, W. (2017). Komitmen profesi dan pengaruhnya terhadap kompetensi profesional guru pada madrasah tsanawiyah di kota Makassar. Jurnal Inspiratif Pendidikan, VI(1), 35-58.

Nursafitri, L. (2015). Improving the quality of learning through lesson study. Jurnal Pendidikan Sekolah Dasar, 1(2).

Ossiannilsson, E., Altinay, Z., \& Altinay, F. (2016). Transformation of Teaching and Learning in Higher Education towards Open Learning Arenas: A Question of Quality. In In Blessinger P. \& Bliss T. (Eds.), Open Education: International Perspectives in Higher Education (pp. 159-178). Cambridge, UK: Open Book.

Pedersen, A., Nørgaard, R., \& Köppe, C. (2018). Patterns of Inclusion: Fostering Digital Citizenship through Hybrid Education. ournal of Educational Technology \& Society, 21(1), 225-236.

Poernamawijayai, L. W., Sulaiman, Suriansyah, A., \& Dalle, J. (2018). contribution on supervision of supervisor, principals motivation, kindergarten teacher performance to improving the kindergarten quality in West Banjarmasin, Indonesia. European Journal of Alternative Education Studies, 3(2), 129146. doi:10.5281/zenodo.226103.

Rahman, M. (2018). Hasil UNBK SMP se Kalsel menurun, kecuali Banjarmasin dan Kabupaten Banjar. Kanal Kalimantan.

RAND Mathematics Study Panel, \& Ball, D. (2003). TEACHERS' MATHEMATICAL KNOWLEDGE: ITS DEVELOPMENT AND USE IN TEACHING. In In Mathematical Proficiency for All Students: Toward a Strategic Research and Development Program in Mathematics Education (pp. 15-28). Santa Monica, CA; Arlington, VA; Pittsburgh, PA: RAND Corporation.

Rimm-Kaufman, S., \& Sawyer, B. (2004). Primary-Grade Teachers' Self-Efficacy Beliefs, Attitudes toward Teaching, and Discipline and Teaching Practice Priorities in Relation to the "Responsive Classroom" Approach. The Elementary School Journal, 104(4), 321-341.

Rosdiana, D. (2016). Pengaruh kompetensi guru dan komitmen mengajar terhadap efektivitas proses pembelajaran serta implikasinya pada hasil belajar siswa dalam mata pelajaran ekonomi. Jurnal Penelitian Pendidikan, 13(2), 1-10.

Rusman. (2012). Model-model pembelajaran: Mengembangkan profesionalsime guru. Rajawali Pers.

Saliyeva, S., \& Levesley, J. (2018). Learning-oriented assessment. In In Tong V., Standen A., \& Sotiriou M. (Eds.), Shaping Higher 
Education with Students: Ways to Connect Research and Teaching (pp. 178-187). London: UCL Press.

Sastrawan, K. (2016). Profesionalisme guru dalam upaya meningkatkan mutu pembelajaran . Jurnal Penjaminan Mutu, 2(2), 63-75.

Shelvia, B., Ahmad, K., \& Mahrita. (2020). Implementation of 2013 Curriculum in Improving Education Quality. Journal of K6, Education and Management, 3(1), 8-16.

Simon, S., Erduran, S., \& Osborne, J. (2006). Learning to teach argumentation: Research and development in the science classroom. International Journal of Science Education. 28(23), 235-260.

Sobri, A. (2013). Pembinaan profesionalisme guru dalam meningkatkan kualitas pembelajaran. Jurnal Manajemen Pendidikan, 24(1), 9-20.

Solomon, C. B. (2007). The relationship among middle level leadership, teacher commitment, teacher collective efficacy, and student achievement.

Sonhadji, A. (2004). Resource sharing antara pendidikan tinggi dan pendidikan menengah dalam meningkatkan kualitas lulusan. Retrieved from Sonhadji Personal Website.

Sudarsana, I. (2018). Pentingnya sekolah bertaraf internasional di Bali. Jurnal Ganaya IImu Sosial Dan Humaniora, 1(1).

Sulaiman, Damai, S., \& Effendi, R. (2019). The Teacher Achievement Motivation as an Intervening Variable in Relationship between Teacher' s Profesionalism, Principal's Leadership and Teacher' $s$ Performance of State High School in Banjarmasin City. Journal of K6, Education and Management, 2(1), 23-35.
Sumani. (2009). Lesson study sebagai salah satu upaya meningkatkan kualitas pembelajaran. Jurnal Pendidikan, 15(1), 1-7.

Surakhmad, W. (2006). Metodologi pengajaran nasional. Jemmars. Suriansyah, A., \& Aslamiah, H. (2012). Menuju kepala sekolah efektif dari teoritis ke praktis. Rumah Pengetahuan.

Susilo, H. (2013). Lesson study sebagai sarana meningkatkan kompetensi pendidik.

Taurina, Z. (2015). Students Motivation and Learning Outcomes: Significant Factors in Internal Study Quality Assurance System. International Journal for Cross-Disciplinary Subjects in Education (IJCDSE), 5(4), 2625-2630.

Tayibnapis, A., Wuryaningsih, L., \& Gora, R. (2018). Indonesia's Efforts to Achieve Globally Competitive Human Resources . International Journal of Humanities and Social Science Invention, 7(8), 1-6.

Toch, T. (2010). Teacher Unions Are Dead! Long Live Teacher Unions! he Phi Delta Kappan, 92(4), 72-73.

Tuğrul Mart, Ç. (2013a). A Passionate Teacher: Teacher Commitment and Dedication to Student Learning. International Journal of Academic Research in Progressive Education and Development, 2(1), 437-442.

Tuğrul Mart, Ç. (2013b). Commitment to School and Students. International Journal of Academic Research in Business and Social Sciences, 3(1), 336-340.

Winarsih, A., \& Mulyani, S. (2012). Increased professionalism of science teachers through lesson study in developing $\mathrm{PBI}$ learning models. Jurnal Pendidikan IPA Indonesia, 1(1), 43-50.

Zakirova, R. (2016). The structure of primary school teachers' professional competence. International Journal of Environmental and Science Education, 11(6), 1167-1173. 